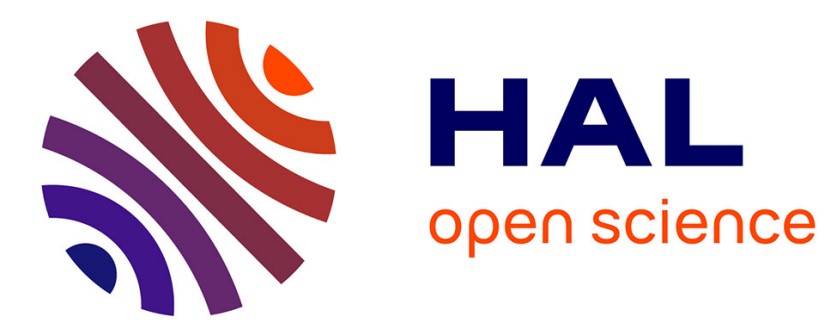

\title{
THE OPTICAL SPECTRA OF Co2+ IN MgAl2O4 SPINEL
}

P. Deren, W. Strek, B . Jezowska-Trzebiatowska, I. Trabjerg

\section{To cite this version:}

P. Deren, W. Strek, B . Jezowska-Trzebiatowska, I. Trabjerg. THE OPTICAL SPECTRA OF Co2+ IN MgAl2O4 SPINEL. Journal de Physique IV Proceedings, 1991, 01 (C7), pp.C7-279-C7-283. 10.1051/jp4:1991776 . jpa-00251019

\section{HAL Id: jpa-00251019 https://hal.science/jpa-00251019}

Submitted on 1 Jan 1991

HAL is a multi-disciplinary open access archive for the deposit and dissemination of scientific research documents, whether they are published or not. The documents may come from teaching and research institutions in France or abroad, or from public or private research centers.
L'archive ouverte pluridisciplinaire HAL, est destinée au dépôt et à la diffusion de documents scientifiques de niveau recherche, publiés ou non, émanant des établissements d'enseignement et de recherche français ou étrangers, des laboratoires publics ou privés. 


\section{THE OPTICAL SPECTRA OF $\mathrm{Co}^{2+} \mathrm{IN} \mathrm{MgAl}_{2} \mathrm{O}_{4}$ SPINEL}

P.J. DEREŃ, W. STREK, B. JEZOWSKA-TRZEBIATOWSKA and I. TRABJERG*

Institute of Low Temperatures and Structure Research Polish Academy of Sciences, P.O. Box 937, PL-50-950 Wroctaw, Poland

${ }^{*}$ H.C. Crsted Institute, Copenhagen University, DK-2100 Copenhagen, Denmark

Abstract. The spectroscopic properties of $\mathrm{MgAl}_{2} \mathrm{O}_{4}$ spinel doped by $\mathrm{Co}^{2+}$ ions are characterized by low ligand fields strength. In result the broad fluorescence band was observed in visible region.

\section{Introduction}

The spin-alloked d-d luminescence transitions in transition metal doped crystals are characterized by the broad band offering a practical utilization for tunable laser operation. The room temperature laser operation in visible range was observed for $\mathrm{Cr}^{3+}[1]$ and $\mathrm{Ti}^{3+}$ ions $[2]$.

Cobalt(II) ion is a counter partner to $\mathrm{Cr}^{3+}$ ion, so their energy 1 evel schemes are similar. The principal difference is associated with much yeaker ligand field strength observed for $\mathrm{Co}^{2+}$ ion. In result the emission arising from the first excited state ${ }^{4} T_{2}$ is observed in the infrared. The laser operations for $\mathrm{Co}^{2+}$ has been reported for a number of crystals but only at lowered temperature and for infrared region [3]. The broad band luminescence in the visible region was recently reported for $\mathrm{Co}^{2+}$ doped $\mathrm{LiGa}_{5} \mathrm{O}_{8}[4]$.

In this paper we present the results of spectroscopic measurements of $\mathrm{Co}^{2+}$ doped $\mathrm{MgAl}_{2} \mathrm{O}_{4}$ spinel. This system exhibits a visible luminescence in room temperature. 


\section{Results}

The absorption spectrum of $\mathrm{MgAl}_{2} \mathrm{O}_{4}$ : $\mathrm{Co}^{2+}$ was $\mathrm{first}$ reported by Drifford [5]. The results of our investigation are shown in Figure 1 .

Table I. Energy levels of $\mathrm{Co}^{2+}$ in spinel $\mathrm{MgA}_{2} \mathrm{O}_{4}$

\begin{tabular}{|c|c|c|}
\hline Level & $\begin{array}{l}\text { Energy } \\
{\left[\mathrm{cm}^{-1}\right]}\end{array}$ & $\mid \begin{array}{l}\text { Re } 1 . \\
\text { inten } \\
\text { sity } \\
{[\%]}\end{array}$ \\
\hline $\begin{array}{l}\mathbf{G}_{1,2} \\
\mathbf{G} \\
\mathbf{E}_{5 / 2}\end{array}$ & $\begin{array}{l}4058 \\
4174 \\
4223 \\
4366 \\
4826\end{array}$ & $\begin{array}{l}1 \\
2 \\
4 \\
5 \\
5\end{array}$ \\
\hline $\begin{array}{c}G, E_{1 / 2} \\
G \\
E_{5 / 2}\end{array}$ & $\begin{array}{l}6452 \\
7300 \\
8026\end{array}$ & $\begin{array}{l}25 \\
23 \\
18\end{array}$ \\
\hline $\begin{array}{c}G, E_{5,2} \\
G \\
E_{1 / 2} \\
{ }^{2} T_{1} C^{2}{ }_{G} \\
\left.{ }_{E} C^{2} G\right)\end{array}$ & $\begin{array}{l}14960 \\
15725 \\
15974 \\
16835 \\
17212\end{array}$ & $\begin{array}{r}1 \\
73 \\
84 \\
87 \\
100\end{array}$ \\
\hline$\left.{ }^{2} T_{2}{ }^{2} G\right)$ & $\begin{array}{l}17870 \\
18349 \\
19198\end{array}$ & $\begin{array}{l}67 \\
55 \\
21\end{array}$ \\
\hline${ }^{2} T_{1} C$ & $\begin{array}{l}20758 \\
22075\end{array}$ & $\begin{array}{l}4 \\
0.7\end{array}$ \\
\hline$\left.{ }^{2} T_{1} c^{2} P\right)$ & 24570 & 0.6 \\
\hline$\left.{ }^{2} T_{2} c^{2} D_{1}\right)$ & 27550 & 0.1 \\
\hline${ }^{2} T_{1} C^{2} F$ & 36530 & D. 8 \\
\hline
\end{tabular}
The absorption spectra were measured at $3.8 \mathrm{~K}$. The absorption bands extend from far infrared to ultraviolet. The assignments of energy transitions as well as relative intensity of each line are shown in Table 1 . Two first bands are assigned to ${ }^{4} \mathrm{~A}_{2}(\mathrm{~F}) \rightarrow{ }^{4} \mathrm{~T}$ (F) and ${ }^{4} A_{2}(F) \rightarrow{ }^{4} T_{1}(F)$ transition. The splitting of this bands is caused by presence of spin-orbit coupling. The strongest band centered at $17200 \mathrm{~cm}^{-1}$ ras assioned to the ${ }^{4} A_{2}(F) \rightarrow{ }^{4} T_{1}$ (P) transition and to the transitions from the ground level ${ }^{4} A_{2}(F)$ to levels from ${ }^{2} G$ term. The intensities of other bands are much peaker relatively to the strongest band (see Tab I). The luminescence spectra of $\mathrm{MgAl}_{2} \mathrm{O}_{4}: \mathrm{Co}^{2+}$ were observed in $77 \mathrm{~K}$ and room temperature. The luminescence measured in $77 \mathrm{~K}$ is shown in Figure 2. The band in visible region is assigned to the ${ }^{4} T_{1}$ (P) $\rightarrow{ }^{4} \mathrm{~A}_{2}$ (F) transition : the band in infrared is assigned to the ${ }^{4} T_{1}$ (P) $\rightarrow{ }^{4} A_{2}$ (F) transition. Red band, centered at $14550 \mathrm{~cm}^{-1}$ is structureless in room temperature, but for $514.5 \mathrm{~nm}$ excitation a small hump is appear in $15128 \mathrm{~cm}^{-1}$. At $77 \mathrm{~K}$ the transition exhibits two strong maxima at $14550 \mathrm{~cm}^{-1}$ and $15128 \mathrm{~cm}^{-1}$. The infrared band has two maxima cat $10880 \mathrm{~cm}^{-1}$ and at $11580 \mathrm{~cm}^{-1}$, in both temperatures. 


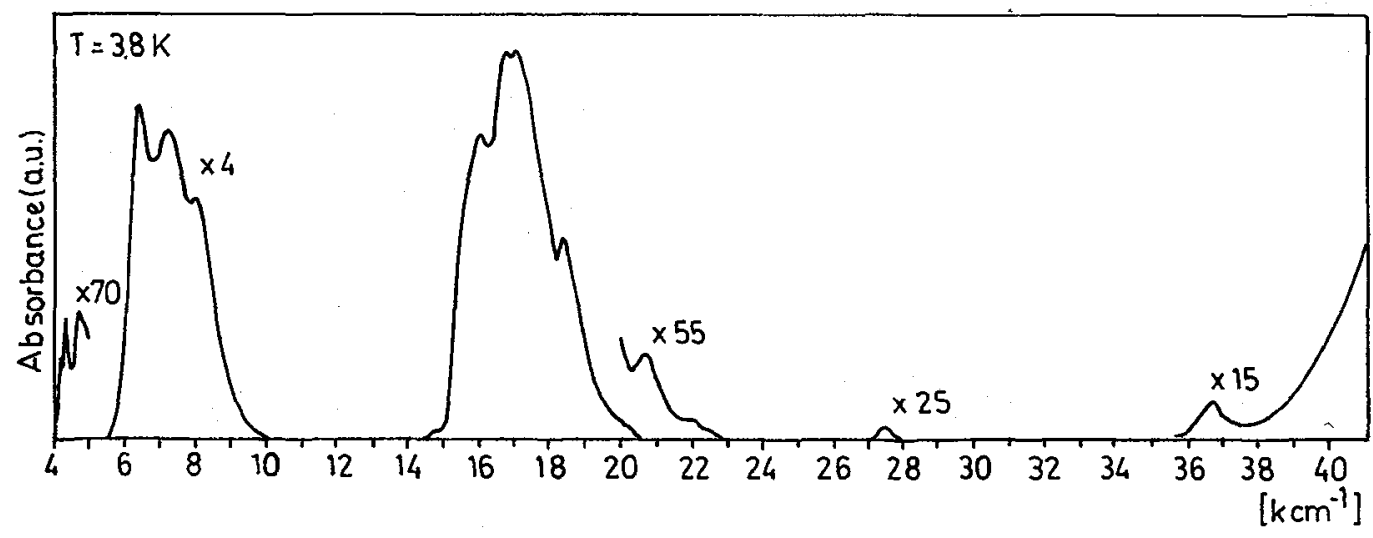

Fig. 1. Absorption spectra of $\mathrm{MgAl}_{2} \mathrm{O}_{4}: \mathrm{Co}^{2+}$ at $3.8 \mathrm{~K}$.

The decay time was measured only in visible region. The observed decay curve was exponential. The decay time in liquid nitrogen temperature was about $220 \mathrm{~ns}$, and $155 \mathrm{~ns}$ in room temperature.

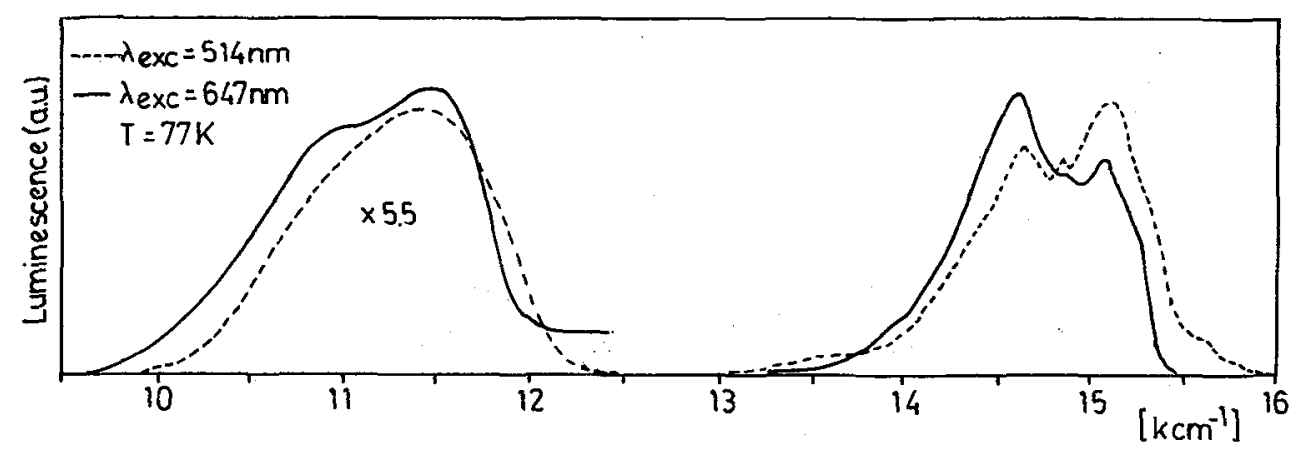

Fig. 2. Fluorescence of $\mathrm{MgAl}_{2} \mathrm{O}_{4}: \mathrm{Co}^{2+}$ for two excitation at $77 \mathrm{~K}$.

Figure 3 shows the temperature dependence of luminescence intensity for both bands. Figure 4 presents the temperature dependence of intensity of visible band to intensity of infrared band. Both dependencies have this same feature. It is an inflexion point at temperature about $350 \mathrm{~K}$.

\section{Discussion}

The results of absorption measurements pere used for calculation the crystal field, Racah's parameters and spin-orbit coupling constant. 
We have obtained $\mathrm{Dq}=402 \mathrm{~cm}^{-1}, \mathrm{~B}=815 \mathrm{~cm}^{-1}, \mathrm{C}=3266 \mathrm{~cm}^{-1}$ and $|\lambda|=275 \mathrm{~cm}^{-1}$. The small value of Dq parameter pointed on the tetrahedral symmetry of $\mathrm{Co}^{2+}$ ions in $\mathrm{MgAl}_{2} \mathrm{O}_{4}$; The parameter $|\mathrm{x}|$ is higher then for free ion $\left.c|\lambda|_{\text {free ion }}=178 \mathrm{~cm}^{-1}\right)$. It may be explained by the presence of local deformation disturbing the positions of multiplets ${ }^{4} T_{1}(F)[5]$.
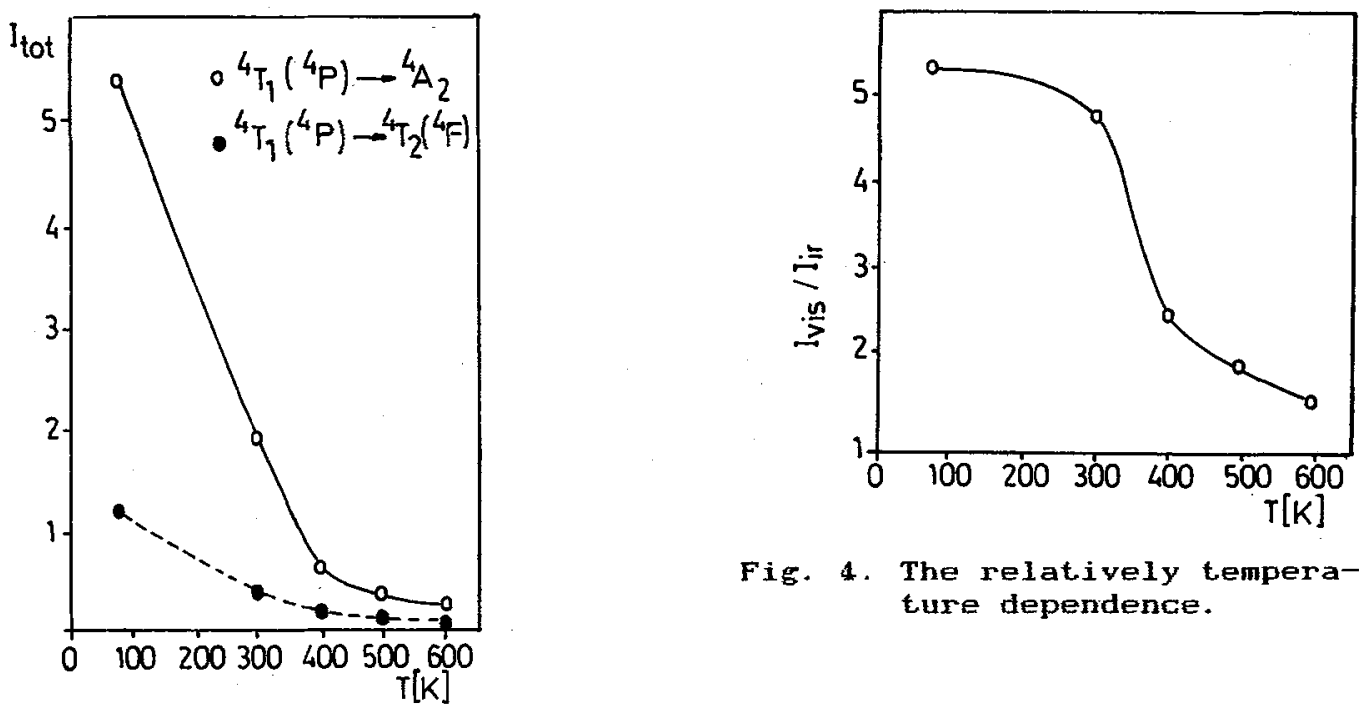

Fig. 4. The relatively temperature dependence.

Fig. 3. Temperature dependence of fluorescence intensity.

The value $\mathrm{Dq} / \mathrm{B}=0.5$ plays this same role for tetrahedral configuration $d^{7}$ ions as $D q / B=2.3$ for $d^{3}$ ions for octahedral coordination. In these points the ${ }^{2}$ E term cross the terms $\left.{ }^{4} T_{1}{ }^{4} P\right)$ and $\left.{ }^{4} \mathrm{~T}_{1} \mathrm{C}^{4} \mathrm{~F}\right)$.

If $\mathrm{Dq} / \mathrm{B}<0.5$ the ${ }^{4} \mathrm{~T}_{1}(\mathrm{P})$ lies below the ${ }^{2} \mathrm{E}$ level giving broad band emission with a short lifetime (the weak field case), while for the strong field case $(D q / B>0.5)$ the term ${ }^{2} E$ is lowest giving a narrow emission with longer lifetime. In $\mathrm{MgAl}_{2} \mathrm{O}_{4}: \mathrm{Co}^{2+} \mathrm{Dq} / \mathrm{B}=0.493$ it's a low field case.

The band maximum in the visible range is located at $14550 \mathrm{~cm}^{-1}$. In perature $77 \mathrm{~K}$ this band is more structured. The position of the peak assigned to the ${ }^{4} \mathrm{~T}_{1}(\mathrm{P}) \rightarrow{ }^{4} \mathrm{~A}_{2}$ (F) transition was not changed. The second strong peak, which dominates for $514.5 \mathrm{~nm}$ excitation, was identified with the transition ${ }^{2} \mathrm{~T}_{2} \rightarrow{ }^{4} \mathrm{~A}_{2}(\mathrm{~F})$.

Two maxima of infrared emission were simply identified with the transition to $E_{5 / 2}$ and $E_{1 / 2}$ fine levels of ${ }^{4} T_{2}(F)$ term.

A fast radiative decay rate confirms allowed electric-dipole character of these transitions. 


\section{Conclusion}

The $\mathrm{Co}^{2+}$ ions exhibits a strong preference to the location in tetrahedral symmetry. Such symmetry. was reported in many hosts $[6]$, [7]. An octahedral symmetry was reported only in a few cases [8].

The $\mathrm{Co}^{2+}$ in $\mathrm{MoAl}_{2} \mathrm{O}_{4}$ spinel is characterized, as we shown, by tetrahedral-symmetry. This assignment is confirmed by small value of Dq parameter.

The visible broad band emission due to the low ligand field CDq/B 6 0.5) yas observed to be efficient at room temperature. It may be utilized for tunable laser operation.

\section{References:}

1. P. T. Kenyon, L. Andrews, B. McCollum and A.Lempicki, IEEE J. Quant, Elect., QE18, (1982)1189.

2. F. Multon, Laser Focus (1983)83.

3. A. A. Kaminskii, Laser Grystals, Springer Verlag (1981).

4. J.F.Donegan, F.J.Bergin and G.F.Imbush, J.Lumin. 31,32 (1984)278

5. M. Drifford et P.Rigny C, R. Acad.SC, Paris, t. 263, serie B 619663180 .

6. R. Pappalaardo, D.L. Wood and R. C.Linores Jx. J. Chem. Fhys. 35 (1961) 2041 .

7. D. L. Wood and J.P.Remeika J.Chem. Phys., 46 C1967>3595.

8. L.F. Johnson, R. E. Dietz and H. I. Guggenheim Apl1. Fhys. Let, 5 $(1964) 21$. 